\title{
Pineapple harvest index and fruit quality improvement by application of gibberellin and cytokinin
}

\author{
Tri Suwandi ${ }^{1, \star}$, Kumala Dewi ${ }^{1}$ and Priyo Cahyono ${ }^{2}$ \\ 1 Faculty of Biology, Gadjah Mada University, Yogyakarta, Indonesia \\ 2 Research and Development Department, Great Giant Pineapple company, Lintas Sumatera street, Km. 77 Terbanggi Besar, \\ Lampung, Indonesia
}

Received 23 November 2015 - Accepted 18 April 2016

\begin{abstract}
Introduction. Gibberellin application alone in Lampung, Indonesia, has not been successful in overcoming the low harvest index of pineapple. Cytokinin is known to promote the allocation of assimilates to sink organs. The effect of gibberellin and cytokinin on the harvest index and fruit quality of pineapple was evaluated in this study. Materials and methods. Three levels of gibberellin $(0,100$ and $200 \mathrm{ppm})$ combined with three levels of cytokinin $(0,24$ and $48 \mathrm{ppm})$ were applied in the $12^{\text {th }}$ and $14^{\text {th }}$ weeks after flowering induction treatment. The experiment was conducted with the pineapple cv. Smooth Cayenne in a randomized complete block design with three replications. Harvest index and fruit quality analyses were carried out in fruits harvested during the $23^{\text {rd }}$ week after flowering induction treatment. Results and discussion. Gibberellin alone (100 or $200 \mathrm{ppm}$ ) or combined with cytokinin (24 or $48 \mathrm{ppm}$ ) increased the fruit weight, harvest index and fruit crown length - a positive effect on the quality of this planting material - and delayed fruit maturity (5 days) of 'Smooth Cayenne' pineapple. Conclusion. Gibberellin and/or cytokinin improved some properties of the pineapple fruit quality. Treatment with $100 \mathrm{ppm}$ of gibberellin combined with 24 ppm of cytokinin was the best treatment for improvement of the pineapple harvest index and fruit quality.
\end{abstract}

Keywords: Indonesia / pineapple / Ananas comosus / plant growth regulators / crop management / fruit maturity

Résumé - Amélioration de l'indice de récolte et de la qualité du fruit de l'ananas par application de gibbérellines et de cytokinines. Introduction. L'application de gibbérellines seules n'a pas réussi à contrecarrer la faiblesse de l'indice de récolte de l'ananas à Lampung, en Indonésie. Les cytokinines sont connues pour favoriser la répartition des assimilats qui alimentent organes. Les effets combinés des gibbérellines et des cytokinines sur le point de récolte et sur la qualité du fruit de l'ananas ont été étudiés. Matériels et méthodes. Trois doses de gibbérellines $(0,100$ et $200 \mathrm{ppm})$ combinées à trois doses de cytokinines $(0,24$, et $48 \mathrm{ppm})$ ont été appliquées durant les semaines 12 et 14 après le traitement d'induction de la floraison. L'expérience a été menée sur le cv. Cayenne lisse en bloc complet randomisé avec trois répétitions. Le calcul de l'indice de récolte et l'analyse qualitative des fruits ont été réalisés sur les fruits récoltés au cours de la $23^{\mathrm{e}}$ semaine après traitement d'induction de la floraison. Résultats et discussion. Les gibbérellines seules (100 ou 200 ppm) ou en combinaison avec des cytokinines ( 24 ou 48 ppm) ont augmenté le poids des fruits, l'indice de récolte, la longueur de la couronne des fruits - un effet positif pour la qualité de ce matériel de plantation - et ont retardé (de 5 jours) la maturité des fruits du 'Smooth Cayenne'. Conclusion. Les gibbérellines et/ou cytokinines améliorent certains critères de qualité du fruit de l'ananas. La combinaison de 100 ppm de gibbérellines et de 24 ppm de cytokinines s'est montré le meilleur traitement pour l'amélioration de l'indice de récolte et la qualité des fruits de l'ananas.

Mots clés : Indonésie / ananas / Ananas comosus / hormones végétales de croissance / gestion des cultures / maturité des fruits

Abbreviations. GA : gibberellin ; CK : cytokinin; ABA : abscisic acid ; PGR : plant growth regulator ; ppm : part per million; DAF : day after flowering induction treatment; TSS : total soluble solids; TA : titratable acidity.

\footnotetext{
^ Corresponding author: tri.suwandi@mail.ugm.ac.id
} 


\section{Introduction}

The pineapple fruit is technically called a sorosis - "a fusion of many fruits together to form one unit". Each "eye" (fruitlet) is a complete fruit. Flowering starts at the bottom of the sorosis and continues up as a spiral to the last eye. When the formation of fruitlets stops, the growing point reverts to a vegetative state and the top (crown) is formed [1]. There is probably no direct effect of the crown on the growth of the fruit and no relationship among the crown, fruit size and stem starch [2]. Fruit growth from blossoming inflorescence to mature fruit results in a twenty-fold increase in weight. The enlargement of the calyx results from continued growth by cellular division, in the stages up to flowering, and cell enlargement, in the later stages [3]. Fruit growth is more rapid around 100 days after the flowering induction treatment when there is a decrease in stem dry matter and probably in stem starch, or both, indicating a mobilization of starch from the stem to help meet the fruit carbon demand. Leaf starch is apparently also mobilized to meet the increasing demand for the rapidly developing fruit [4]. Good cultural care will ensure a large number of fruitlets are formed, which will fill out to give a well-shaped and high-yielding fruit.

In some pineapple plantations of the Great Giant Pineapple (GGP) company, Indonesia, there has been a decrease in productivity and fruit quality, resulting in small fruits or large fruits with small-sized crowns or with a conical shape. This is disadvantageous because the crown is one of the main pineapple planting materials. Therefore, the goal is always to obtain the best fruit quality with vigorous crowns. An effort to overcome this problem is by applying plant growth regulators (PGRs). Gibberellin (GA) plays a role in increasing the sourcesink relation or sink strength by activating enzymes involved in sugar metabolism [5,6]. The partitioning of assimilates from source leaves is a key factor for fruit development, as any limitation of assimilate supply affects the final fruit size [7]. Gibberellin is a PGR commonly used to increase fruit weight in various types of plants. Gibberellin increases the fruit number and size of grapes, delays maturity and reduces physiological abnormalities in citrus peel, maintains the photosynthetic tissue of lemon peel, and extends the postharvest shelf life of banana [8]; it increases the fruit weight of 'Comte de Paris' pineapple [9]; it delays the maturity of 'MD-2' pineapple for 7-10 days, and increases its crown length [8]. Previous studies conducted at GGP have shown that GA increased the pineapple fruit size, but the internal fruit quality was poor due to such aspects as more translucency, bland taste and variable TSS/TA ratio (personal communication, 2013). These results may have been affected by inappropriate time of application and concentrations of GA.

It is known that plant hormones do not work by themselves to stimulate or inhibit the growth, but they interact with other hormones or components. Besides GA, cytokinin (CK) is also a hormone that stimulates cell division and growth, controls cell division and cell differentiation, and triggers the nutrient mobilization and allocation from the source to the sink organs [10]. The interactions between GA and CK include both negative and positive mutual regulation, depending on the tissue and signaling context. Also, numerous antagonistic effects on developmental processes and signaling are exerted by GA and CK $[11,12]$. Previous studies have shown that GA and CK have a synergistic relationship to increase the fruit weight of 'Hass' avocado [13] and 'Golden Delicious' and 'Jonagold' apples [14]. To our knowledge, there is no information on CK or the interaction between GA and $\mathrm{CK}$ in pineapple. Moreover, no studies have been conducted to evaluate the harvest index, and physical and biochemical quality of the fruit in response to GA and CK application in 'Smooth Cayenne' pineapple. The effect of GA and CK on the harvest index, and fruit and crown quality of 'Smooth Cayenne' pineapple is reported in the present study.

\section{Materials and methods}

\subsection{Experimental design}

The experiment was conducted at the research station of GGP located in Terbangi Besar, Lampung, Indonesia, from August 2014 until February 2015. The experimental station has the following geographic coordinates: $4^{\circ} 49^{\prime} 15.5^{\prime \prime} \mathrm{S}$ and $105^{\circ} 15^{\prime} 27.4$ " E, with an average altitude of around $46 \mathrm{~m}$. The average annual rainfall is about $148.4 \mathrm{~mm}$, average annual temperature is $27.5^{\circ} \mathrm{C}$, and average relative air humidity is $88.6 \%$.

Ground suckers of 'Smooth Cayenne' pineapple (about $40 \mathrm{~cm}$ in length) were planted in August 2013. A plantation of 67,340 plants $\times$ ha $^{-1}$ was maintained with a single-row planting system $(55 \mathrm{~cm} \times 27 \mathrm{~cm})$. Flower induction was performed at 12 months after planting (August 2014) by spraying with $3 \mathrm{~kg} \times \mathrm{ha}^{-1}$ of ethylene, $25 \mathrm{~kg} \times \mathrm{ha}^{-1}$ of kaolin and $50 \mathrm{~kg} \times$ $\mathrm{ha}^{-1}$ of urea dissolved in $4,000 \mathrm{~L} \times \mathrm{ha}^{-1}$ of water.

The experiment was conducted in a randomized complete block design with three replications. The experimental plot $(5.5 \mathrm{~m} \times 2.7 \mathrm{~m})$ consisted of at least 110 plants in 10 rows and there were border plants between plots. A factorial arrangement of treatments that consisted of ProGibb ${ }^{\circledR}$ 40SG (GA3) levels of 0, 100 and $200 \mathrm{ppm}$ active ingredient (a.i.) and Novelgro Alpha (zeatin:kinetin, 3:1 v/v; CK) levels of 0, 24 and 48 ppm a.i. (table I) were applied at 12 weeks after forcing (November 28, 2014) and again at 14 weeks after forcing (December 11, 2014). The solution was sprayed until runoff using approximately $10-15 \mathrm{~mL}$ of solution per fruit in each application, which was done with a knapsack sprayer in the morning.

\subsection{Analysis of pineapple harvest index and fruit quality}

Five fruits at the mature green stage, reached at $156 \mathrm{DAF}$, were harvested per treatment plot for fruit quality analysis. Meanwhile, the remaining fruits were harvested as they reached the half-yellow stage when fruit were designated as mature. The data on days from induction to harvest for all fruits within each treatment were averaged to assess the effect of the PGR treatments on days from induction to fruit maturity. The fresh weights of the fruit, crown and plant, without roots, were 
Table I. Effect of gibberellin and cytokinin on the fruit weight, crown length and harvest index of pineapple.

\begin{tabular}{ccccc}
\hline Treatments & Fruit weight $(\mathrm{g})$ & Crown length $(\mathrm{cm})$ & Harvest index & Days to maturity \\
\hline $\mathrm{GA}_{0} \mathrm{CK}_{0}$ & $1165.56^{\mathrm{b}}$ & $22.29^{\mathrm{d}}$ & $0.50^{\mathrm{c}}$ & 161 \\
$\mathrm{GA}_{0} \mathrm{CK}_{1}$ & $1125.00^{\mathrm{b}}$ & $23.78^{\mathrm{d}}$ & $0.48^{\mathrm{d}}$ & 161 \\
$\mathrm{GA}_{0} \mathrm{CK}_{2}$ & $1238.33^{\mathrm{ab}}$ & $22.09^{\mathrm{d}}$ & $0.53^{\mathrm{a}-\mathrm{c}}$ & 161 \\
$\mathrm{GA}_{1} \mathrm{CK}_{0}$ & $1414.00^{\mathrm{a}}$ & $29.77^{\mathrm{ab}}$ & $0.55^{\mathrm{ab}}$ & 166 \\
$\mathrm{GA}_{1} \mathrm{CK}_{1}$ & $1459.78^{\mathrm{a}}$ & $27.37^{\mathrm{bc}}$ & $0.56^{\mathrm{a}}$ & 166 \\
$\mathrm{GA}_{1} \mathrm{CK}_{2}$ & $1235.56^{\mathrm{ab}}$ & $26.81^{\mathrm{c}}$ & $0.54^{\mathrm{a}-\mathrm{c}}$ & 166 \\
$\mathrm{GA}_{2} \mathrm{CK}_{0}$ & $1235.83^{\mathrm{ab}}$ & $29.09^{\mathrm{a}-\mathrm{c}}$ & $0.52^{\mathrm{c}}$ & 166 \\
$\mathrm{GA}_{2} \mathrm{CK}_{1}$ & $1318.56^{\mathrm{ab}}$ & $31.07^{\mathrm{a}}$ & $0.55^{\mathrm{ab}}$ & 166 \\
$\mathrm{GA}_{2} \mathrm{CK}_{2}$ & $1458.44^{\mathrm{a}}$ & $28.89^{\mathrm{a}-\mathrm{c}}$ & $0.58^{\mathrm{a}}$ & 166 \\
\hline
\end{tabular}

${ }^{1}$ Fruit treatments were $0\left(\mathrm{GA}_{0}\right), 100\left(\mathrm{GA}_{1}\right)$ or $200\left(\mathrm{GA}_{2}\right)$ ppm of gibberellic acid and $0\left(\mathrm{CK}_{0}\right), 24\left(\mathrm{CK}_{1}\right)$ or $48\left(\mathrm{CK}_{2}\right)$ ppm of cytokinin. All fruits were harvested at the half-yellow stage.

${ }^{2}$ Values are means for 45 fruits. Values within a column followed by the same letter are not significantly different $(P<0.05)$ according to Duncan's multiple range test.

${ }^{3}$ Days to maturity (DTM) were the number of days from induction on 04-08-2014 to fruit maturity.

measured on 15 fruits from each treatment plot. The harvest index was calculated based on the ratio of fruit weight at harvest (without the crown) to the plant weight at harvest [15].

Five samples of fruits were sliced horizontally at the point of the largest diameter. Internal fruit maturity indices were evaluated using a subjective color chart varying from 0 to 6 ; with 0 being a completely white flesh and 6 a completely yellow one (available at http://www.verita.cr/internal.jpg). Immature fruits have a white flesh color, while mature or ripe fruits have a yellowish-white flesh. The flesh also becomes slightly translucent in appearance at maturity. Fruits are over-mature when more than half of the cross-sectional area of the fruit is translucent [16].

Fruit firmness was measured on triangle regions of fruit slices taken from the middle part using a penetrometer (Instron 5542) and results were expressed as N.

The fruit shell, core, and the top and bottom $3 \mathrm{~cm}$ of flesh were removed, then the flesh was taken for biochemical fruit quality analysis. The flesh was cut into small pieces and the juice was extracted with a small benchtop juice extractor. To determine the total soluble solids (TSS) content, the filtrate was measured by a hand refractometer. Titratable acidity (TA) was measured using filtrate titration with $0.1 \mathrm{~N}$ of $\mathrm{NaOH}$ until it reached the titration end point ( $\mathrm{pH} 8.3$ ).

Water content was analyzed using the thermogravimetric method. Samples were heated in an oven at a temperature of $100-105^{\circ} \mathrm{C}$ for $3 \mathrm{~h}$ to reach constant mass. The difference in weight before and after drying was the amount of water contained in the sample.

Fruit fiber content was analyzed by alcohol extraction and the thermogravimetric method. Ten grams of the juice were put in a boiling flask and $200 \mathrm{~mL}$ of boiled $0.255 \mathrm{~N} \mathrm{H}_{2} \mathrm{SO}_{4}$ were added. This apparatus was placed on the condenser and heated for $30 \mathrm{~min}$. Once completed, the suspension was filtered and the residue was washed with distilled water until the washing water was no longer acidic (tested with litmus paper). The residue was transferred quantitatively from the filter paper back into the boiling flask with a spatula. The remaining residue was washed with $200 \mathrm{~mL}$ of boiled $0.313 \mathrm{~N}$ of $\mathrm{NaOH}$. The flask was boiled again on the condenser for $30 \mathrm{~min}$. The suspension was filtered through filter paper while being washed with boiling distilled water until the washing water was no longer basic (tested with a PP indicator). The residue was washed with boiling distilled water containing $15 \mathrm{~mL}$ of alcohol $95 \%$. The residue present in the filter paper was dried at a temperature of $100-110^{\circ} \mathrm{C}$ for $1-3 \mathrm{~h}$ until it reached constant mass, cooled in the desiccator, and weighed. The difference in weight of the filter paper and residue before and after drying was the percentage of fibers contained in the sample.

The vitamin $\mathrm{C}$ content of the fruit flesh was determined by titration of the filtrate with 2.6-dichlorophenol indophenol (2.6-D). The filtrate was put into a $250-\mathrm{mL}$ Erlenmeyer flask and distilled water was added up to the mark. Five $\mathrm{mL}$ of filtrate were put into a $100-\mathrm{mL}$ Erlenmeyer flask and $5 \mathrm{~mL}$ of $\mathrm{HPO}_{3}$-acetatic acid were added. The mixture was titrated with a standard solution of 2.6-D until the color changed to pink. At the end point of the titration, the solution volume was recorded.

For fruit potassium content determination, $20 \mathrm{~mL}$ of the juice were put into a $25-\mathrm{mL}$ volumetric flask and $40 \mathrm{~g} \mathrm{~L}^{-1} \mathrm{CsCl}$ solution was added until the content in the sample reached about $0.1-0.4 \%$. The solution was diluted 5 times. The blank solution was $0.1-0.4 \%$ of $\mathrm{CsCl}$ solution. Standard solution absorbance was measured using an atomic absorbance spectrometer (AAS) at the wavelength of $769.9 \mathrm{~nm}$. The standard curve was done afterwards. The absorbance of the sample solution was also measured by AAS.

The sugar content of the pineapple fruits was analyzed using high-performance liquid chromatography (HPLC). Fructose, glucose and sucrose standards were purchased from Merck. The sugar content in the sample was calculated by comparing the sample's peak area with the standards at the wavelength of $250 \mathrm{~nm}$. The mobile phase used was acetonitrile and distilled water $(80: 20 ; \mathrm{v} / \mathrm{v})$. The stationary phase used was a Purospher Star $\mathrm{NH}_{2}$ 250-4 $\mu$ m column with a RI detector at a temperature of $40{ }^{\circ} \mathrm{C}$, flow rate of $1 \mathrm{~mL} \mathrm{~min}^{-1}$ and volume injection of $20 \mu \mathrm{L}$. 


\subsection{Statistical analysis of data}

Data were analyzed using analysis of variance (ANOVA) followed by Duncan's multiple range test (DMRT) at the 5\% level.

\section{Results and discussion}

\subsection{Effect of gibberellin and cytokinin on the pineapple harvest index}

Pineapple fruit treated with GA alone or in combination with CK slightly increased the fruit weight and harvest index (table I). The harvest index was increased by 6 and $10 \%$ by treatment with $48 \mathrm{ppm}$ of CK and $100 \mathrm{ppm}$ of GA, respectively. However, the treatments of $100 \mathrm{ppm}$ of GA combined with $24 \mathrm{ppm}$ of CK, and $200 \mathrm{ppm}$ of GA combined with $48 \mathrm{ppm}$ of CK showed a significant increase in the harvest index compared with control (12 and 16\%, respectively). Application of GA alone or in combination with CK significantly increased the crown length, which was a positive effect on the quality of this planting material. The fruits not treated with GA matured five days earlier than those treated with GA, while CK had no effect on days to maturity (table I). Similar results were obtained by others [8].

It is known that GA plays a key role in cell expansion [17]. Gibberellin may not increase the number of cells, but increases the cell volume of pineapple fruit [9]. Gibberellin is known to be an important phytohormone that regulates source-sink relations or sink demand by activating enzymes involved in sugar metabolism $[18,19]$. CK also plays an important role in the absorption of water and mobilization of assimilates to the sink organs such as the fruit $[10,20,21]$. Application of GA increased the fruit weight of 'MD-2' [8] and 'Comte de Paris' pineapple [9]. Application of CK increased the fruit weight of Lupinus angustifolius [22] and 'Duke' blueberry [23]. The fact that GA combined with CK increases the fruit weight of nonclimacteric multiple fruits (sorosis) has not been reported.

\subsection{Effect of gibberellin and cytokinin on pineapple fruit quality}

The effect of gibberellin and cytokinin on pineapple fruit quality is shown in tables II and III. As shown in table II, control and fruits treated with CK alone had a more yellowishwhite flesh than fruits treated with GA alone or combined with CK. However, the results indicate that fruit firmness was not affected by GA and CK treatments.

Gibberellin at $100 \mathrm{ppm}$ combined with $24 \mathrm{ppm}$ of CK was the best combination to increase the fruit fiber content by $106.06 \%$ compared with the control (table II). Changes in fruit fiber contents, as determined by GA and CK, may lead to inhibition of the fruit softening [30,31]. Gibberellin is known to inhibit the reduction of the stability of the cell wall [32] by influencing the enzymes involved in this process [27,33-35]. On the other hand, there is no information available on the effects of CK on fruit fiber content. However, CK may improve the function of GA in this mechanism, contributing to increasing the fiber content in pineapple, as was observed for the treatment $\mathrm{GA}_{1} \mathrm{CK}_{1}$ in this study.

Pineapple fruit treated with GA, CK, or the combination of GA with CK significantly increased the fruit water content ( $t a-$ ble II). The water content was increased by $7.07 \%$ in response to application of $200 \mathrm{ppm}$ of GA combined with $24 \mathrm{ppm}$ of $\mathrm{CK}$. This may be related to the effect of GA reducing the water potential in the cell by increasing the plasticity of the cell wall followed by hydrolysis of starch into sugar [36]. The entry of water into the fruit cells helps cell enlargement, thus increasing the fruit size [24]. In addition, CK also plays a role in the absorption of water during fruit growth [10,20,21].

The fruit potassium content was affected by GA and CK. Cytokinin at $24 \mathrm{ppm}$ increased the potassium content by $4.85 \%$, but it was decreased by higher CK concentration (48 ppm) and GA treatments, such as $100 \mathrm{GA}$, which decreased it by $23.86 \%$ compared with the control. Increasing potassium content showed correlation with the water content in pineapple fruit when $\mathrm{CK}$ was applied (table II), an effect related to the osmotic regulation in the cell. Potassium is involved in the charge balance of organic acids in the cell vacuole [37]. Some phytohormones, such as ABA and GA, maintain the balance of osmotic pressure by regulating $\mathrm{K}^{+} / \mathrm{H}^{+}$ exchangers [38]. However, CK has not yet been reported in this context.

The vitamin $\mathrm{C}$ content of fruits treated with GA alone or in combination with $\mathrm{CK}$ was significantly higher than those of the control and CK alone, and there was a significant concentration response (table II). Treatment of $200 \mathrm{ppm}$ of GA combined with $48 \mathrm{ppm}$ of $\mathrm{CK}$ was the best combination, increasing the content of vitamin $\mathrm{C}$ by $78.5 \%$ compared with the control. These results are consistent with those of a previous study which showed that 50 or $100 \mathrm{ppm}$ of GA increased the vitamin $\mathrm{C}$ content of 'MD-2' pineapple fruit [9]. The increase in the vitamin $\mathrm{C}$ content is favored by the delay in the physiological ripening of the pineapple fruit [39]. Vitamin C is an antioxidant compound essential for all parts of a plant, and it also plays a role in cell expansion [40,41]. The increase in the vitamin $\mathrm{C}$ content in pineapple fruits may be one of the reasons why GA increases the fruit cell area and size [9].

The total soluble solids (TSS) and titratable acidity (TA) values of fruits treated with GA and CK were significantly lower than the control, and there was a significant concentration response (table III). For example, TSS were reduced by $19.88 \%$ and TA by $17.02 \%$ in response to application of $100 \mathrm{ppm}$ of GA combined with $48 \mathrm{ppm}$ of CK compared with the control. However, there was no effect of GA and CK on the ratio of sugar to acid (TSS/TA) (table III). These results were different from those obtained in a previous study, where GA increased TSS and TA of 'MD-2' pineapple fruits, and where TSS/TA was increased in low-GA-concentration treatments and decreased in high-level GA treatment [9]. These results may be related to the delay in the fruit physiological maturity in response to GA application [8], as changes of TSS and TA in pineapples are highly correlated with the level of fruit maturity [42-45].

Single treatments of GA or CK also significantly affected the sugar content of 'Smooth Cayenne' pineapple fruits 
Table II. Effect of gibberellin and cytokinin on pineapple fruit quality (part 1). Fruits were collected at 156 DAF (green mature stage). Values are means for 45 fruits.

\begin{tabular}{ccccccc}
\hline Treatments & Flesh color index & Fruit firmness (N) & Fruit fiber (\%) & Water content (\%) & Potassium (ppm) & Vitamin C (ppm) \\
\hline $\mathrm{GA}_{0} \mathrm{CK}_{0}$ & 2 & $288.70^{\mathrm{a}}$ & $0.33^{\mathrm{b}}$ & $81.70^{\mathrm{f}}$ & $117.02^{\mathrm{b}}$ & $9.44^{\mathrm{e}}$ \\
$\mathrm{GA}_{0} \mathrm{CK}_{1}$ & 2 & $281.85^{\mathrm{a}}$ & $0.31^{\mathrm{b}}$ & $85.33^{\mathrm{d}}$ & $122.70^{\mathrm{a}}$ & $9.28^{\mathrm{e}}$ \\
$\mathrm{GA}_{0} \mathrm{CK}_{2}$ & 2 & $304.63^{\mathrm{a}}$ & $0.45^{\mathrm{b}}$ & $84.98^{\mathrm{e}}$ & $108.45^{\mathrm{d}}$ & $9.59^{\mathrm{e}}$ \\
$\mathrm{GA}_{1} \mathrm{CK}_{0}$ & 1 & $291.67^{\mathrm{a}}$ & $0.33^{\mathrm{b}}$ & $84.73^{\mathrm{e}}$ & $89.31^{\mathrm{h}}$ & $14.13^{\mathrm{bc}}$ \\
$\mathrm{GA}_{1} \mathrm{CK}_{1}$ & 1 & $329.07^{\mathrm{a}}$ & $0.68^{\mathrm{a}}$ & $86.76^{\mathrm{b}}$ & $100.56^{\mathrm{f}}$ & $12.31^{\mathrm{cd}}$ \\
$\mathrm{GA}_{1} \mathrm{CK}_{2}$ & 1 & $321.67^{\mathrm{a}}$ & $0.43^{\mathrm{b}}$ & $85.84^{\mathrm{c}}$ & $102.03^{\mathrm{e}}$ & $10.80^{\mathrm{de}}$ \\
$\mathrm{GA}_{2} \mathrm{CK}_{0}$ & 1 & $282.96^{\mathrm{a}}$ & $0.37^{\mathrm{b}}$ & $85.86^{\mathrm{c}}$ & $95.60^{\mathrm{g}}$ & $14.73^{\mathrm{b}}$ \\
$\mathrm{GA}_{2} \mathrm{CK}_{1}$ & 1 & $318.52^{\mathrm{a}}$ & $0.31^{\mathrm{b}}$ & $87.48^{\mathrm{a}}$ & $102.39^{\mathrm{e}}$ & $15.34^{\mathrm{ab}}$ \\
$\mathrm{GA}_{2} \mathrm{CK}_{2}$ & 1 & $299.07^{\mathrm{a}}$ & $0.47^{\mathrm{b}}$ & $85.61^{\mathrm{cd}}$ & $109.74^{\mathrm{c}}$ & $16.85^{\mathrm{a}}$ \\
\hline
\end{tabular}

Values within a column followed by the same letter are not significantly different $(P<0.05)$ according to Duncan's multiple range test.

Table III. Effect of gibberellin and cytokinin on pineapple fruit quality (part 2). Fruits were collected at 156 DAF (green mature stage). Values are means for 45 fruits.

\begin{tabular}{cccccccc}
\hline Treatments & TSS $\left({ }^{\circ}\right.$ Brix $)$ & TA $(\%)$ & TSS/TA & Sucrose $(\%)$ & Fructose $(\%)$ & Glucose $(\%)$ & Sucrose/Hexose \\
\hline $\mathrm{GA}_{0} \mathrm{CK}_{0}$ & $11.92^{\mathrm{a}}$ & $0.47^{\mathrm{a}}$ & $25.25^{\mathrm{a}}$ & $8.17^{\mathrm{a}}$ & $1.65^{\mathrm{b}}$ & $1.93^{\mathrm{b}}$ & $2.28^{\mathrm{d}}$ \\
$\mathrm{GA}_{0} \mathrm{CK}_{1}$ & $10.64^{\mathrm{ab}}$ & $0.41^{\mathrm{ab}}$ & $26.12^{\mathrm{a}}$ & $6.22^{\mathrm{f}}$ & $1.62^{\mathrm{c}}$ & $1.89^{\mathrm{b}}$ & $1.77^{\mathrm{e}}$ \\
$\mathrm{GA}_{0} \mathrm{CK}_{2}$ & $10.25^{\mathrm{ab}}$ & $0.40^{\mathrm{ab}}$ & $26.11^{\mathrm{a}}$ & $6.80^{\mathrm{c}}$ & $1.56^{\mathrm{d}}$ & $1.19^{\mathrm{g}}$ & $2.47^{\mathrm{c}}$ \\
$\mathrm{GA}_{1} \mathrm{CK}_{0}$ & $11.25^{\mathrm{ab}}$ & $0.45^{\mathrm{ab}}$ & $25.58^{\mathrm{a}}$ & $8.14^{\mathrm{a}}$ & $0.95^{\mathrm{i}}$ & $1.30^{\mathrm{e}}$ & $3.62^{\mathrm{a}}$ \\
$\mathrm{GA}_{1} \mathrm{CK}_{1}$ & $10.17^{\mathrm{ab}}$ & $0.43^{\mathrm{ab}}$ & $23.90^{\mathrm{a}}$ & $6.54^{\mathrm{d}}$ & $1.34^{\mathrm{f}}$ & $1.62^{\mathrm{d}}$ & $2.21^{\mathrm{d}}$ \\
$\mathrm{GA}_{1} \mathrm{CK}_{2}$ & $9.95^{\mathrm{b}}$ & $0.39^{\mathrm{b}}$ & $25.62^{\mathrm{a}}$ & $6.80^{\mathrm{c}}$ & $1.03^{\mathrm{h}}$ & $1.23^{\mathrm{f}}$ & $3.01^{\mathrm{b}}$ \\
$\mathrm{GA}_{2} \mathrm{CK}_{0}$ & $10.40^{\mathrm{ab}}$ & $0.42^{\mathrm{ab}}$ & $25.54^{\mathrm{a}}$ & $7.04^{\mathrm{b}}$ & $1.38^{\mathrm{e}}$ & $1.71^{\mathrm{c}}$ & $2.28^{\mathrm{d}}$ \\
$\mathrm{GA}_{2} \mathrm{CK}_{1}$ & $9.51^{\mathrm{b}}$ & $0.40^{\mathrm{ab}}$ & $23.78^{\mathrm{a}}$ & $6.31^{\mathrm{e}}$ & $1.19^{\mathrm{g}}$ & $1.65^{\mathrm{d}}$ & $2.23^{\mathrm{d}}$ \\
$\mathrm{GA}_{2} \mathrm{CK}_{2}$ & $9.55^{\mathrm{b}}$ & $0.41^{\mathrm{ab}}$ & $24.10^{\mathrm{a}}$ & $4.10^{\mathrm{g}}$ & $2.43^{\mathrm{a}}$ & $2.71^{\mathrm{a}}$ & $0.80^{\mathrm{f}}$ \\
\hline
\end{tabular}

Values within a column followed by the same letter are not significantly different $(P<0.05)$ according to Duncan's multiple range test.

including sucrose and hexose (fructose and glucose). For example, application of 200 ppm of GA combined with 48 ppm of CK significantly decreased the sucrose content by $49.78 \%$, increased the fructose content by $47.27 \%$, increased the glucose content by $40.48 \%$, and reduced the sucrose/hexose ratio by $65.03 \%$ compared with the control. Results regarding the effects of GA and CK on fruit sugar have not been consistent. The present study showed that $100 \mathrm{ppm}$ of GA increased the sucrose/hexose ratio, while $200 \mathrm{ppm}$ of GA showed opposite results. This may be related to a mechanism of GA to regulate sucrose and hexose balance in a fruit [19].

\section{Conclusion}

Gibberellin alone (100 or 200 ppm) or combined with cytokinin ( 24 or $48 \mathrm{ppm}$ ) increased the fruit weight, harvest index and fruit crown length - a positive effect on the quality of this planting material - and delayed fruit maturity (5 days) of 'Smooth Cayenne' pineapple. Gibberellin and/or cytokinin affected the physical and biochemical quality of pineapple fruits. Treatment with 100 ppm of gibberellin combined with 24 ppm of cytokinin was the best treatment for increased fruit weight, harvest index and fruit crown length, and improved some properties of fruit quality, such as fruit firmness, fiber content, water content and vitamin $\mathrm{C}$.

Acknowledgements. We thank the Great Giant Pineapple company, Lampung, for financial support of this research, Novelvar company,
Jakarta for supplying cytokinin, and Bina Guna Kimia company, Jakarta, for supplying gibberellin.

\section{References}

[1] Anonymous, The Pineapple, The State of Queensland (Department of Agriculture and Fisheries), 2009.

[2] Paull R.E., Chen C.-C., Postharvest physiology, handling and storage, in: Bartholomew D.P., Paull R.E., Rohrbach K.G. (Eds.), The Pineapple: Botany, production, and uses, CABI Publishing, Honolulu, 2003.

[3] D"Eeckenbrugge G.C., Leal F., Morphology, anatomy and taxonomy, in: Bartholomew D.P., Paull R.E., Rohrbach, K.G. (Eds.), The Pineapple: Botany, production, and uses, CABI Publishing, Honolulu, 2003.

[4] Bartholomew D.P., Malézieux E., Sanewski G.M., Sinclair, E., Inflorescence and fruit development and yield, in: Bartholomew D.P., Paull R.E., Rohrbach, K.G. (Eds.), The Pineapple: Botany, production, and uses, CABI Publishing, Honolulu, 2003.

[5] Zhang C., Tanabe K., Tamura F., Itai A., Yoshida, M., Roles of gibberellins in increasing sink demand in Japanese pear fruit during rapid fruit growth, Plant Growth Regul. 52 (2007) 161172.

[6] Iqbal N., Nazar R., Khan M.I.R., Masood A., Khan N.A., Role of gibberellins in regulation of source-sink relations under optimal and limiting environmental conditions, Current Science 100 (2011) 998-1007.

[7] Zhang C., Tanabe K., Tamura F., Matsumoto K., Yoshida, A., 13C-photosynthate accumulation in Japanese pear fruit during the period of rapid fruit growth is limited by the sink strength of 
fruit rather than by the transport capacity of the pedicel, J. Exp. Bot. 56 (2005) 2713-2719.

[8] Villalobos M., Alfaro K., Carvajal C., Castillo R., Kaiser R., Lopez A., Lopez J., Tolentino P., RyzUp ${ }^{\circledR} 40$ SG delays fruit maturity and increase fruit weight in pineapple cv. MD-2 under Costa Rican growing conditions, in: Newsletter, Pineapple Working Group, Int. Soc. Agri. Sci. 20 (2014) 34-41.

[9] Li Y-H., Wu Y-H., Wu B., Zou M-H., Zhang Z., Sun., Exogenous gibberellic acid increases the fruit weight of 'Comde de Paris' pineapple by enlarging flesh cells without negative effect on fruit quality, Acta Physiol. Plant. 33 (2011) 1715-1722.

[10] Taiz L., Zeiger E., Plant physiology, Third ed., Sinauer Associates, Inc., Sunderland, 2002.

[11] Greenboim-Wainberg Y., Maymon I., Borochov R., Alvarez J., Olszewski N., Ori N., Eshed Y., Weiss, D., Cross talk between gibberellin and cytokinin: The Arabidopsis GA response inhibitor spindly plays a positive role in cytokinin signaling, Plant Cell 17 (2005) 92-102.

[12] Jasinski S., Piazza P., Craft J., Hay A., Woolley L., Rieu I., Phillips A., Hedden P., Tsiantis M., KNOX action in Arabidopsis is mediated by coordinate regulation of cytokinin and gibberellin activities, Curr. Biol. 15 (2005) 1560-1565.

[13] Zilkah S., David I., Yeselson Y., Tamir M., Winer L., Increasing "Hass" avocado fruit size by CPPU and GA application, in: Proceedings of The World Avocado Congress III, 1995.

[14] Bangerth F., Schriider M., Strong synergistic effects of gibberellins with the synthetic cytokinin N-(2-chloro-4-pyridyl)$\mathrm{N}$-phenylurea on partheno-carpic fruit set and some other fruit characteristics of apple, Plant Growth Regul. 15 (1994) 293302.

[15] Oestreicher J., Review on the potential of computer models to support soil conservation and erosion evasion initiatives for pineapple crops in the panama canal watershed, in: Newsletter, Pineapple Working Group, Int. Soc. Agri. Sci. 15 (2008) 12-21.

[16] Anonymous, Postharvest handling technical series: Pineapple, Ministry of Fisheries, Crops and Livestock, Georgetown, 2002.

[17] Matsuo S., Kikuchi K., Fukuda M., Honda I., Imanishi S., Roles and regulation of cytokinins in tomato fruit development, J. Exp. Bot. 63 (2012) 5569-5579.

[18] Iqbal N., Nazar R., Khan M.I.R., Masood A., Khan N.A., Role of gibberellins in regulation of source-sink relations under optimal and limiting environmental conditions, Current Science 100 (2011) 998-1007.

[19] Brenner M.L., Cheikh N., The role of hormones in photosynthate partitioning and seed filling, in: Davies PJ. (Eds). Plant Hormones, Dordrecht, The Netherlands: Kluwer Academic Publishers, 1995.

[20] EhneSS R., Roitsch T., Co-ordinated induction of $\mathrm{mR}$ NAs for extracellular invertase and a glucose transporter in Chenopodium rubrum by cytokinins, Plant J. 11 (1997) 539548.

[21] Liu F-H., Longnecker N., Interactive effect of cytokinin and potassium on sink-source relationships in Lupinus angustifolius, Plant Growth Regul. 00 (2001) 1-6.

[22] Retamales J.B., Palma M.J., Morales Y.A., Lobos G.A., Moggia C.E., Mena C.A., Blueberry production in Chile: current status and future developments, The Revista Brasileira de Fruticultura 36 (2014) 58-67.
[23] Obroucheva N.V., Hormonal Regulation during Plant Fruit Development, Russ. J. Dev. Biol. 45 (2014) 11-21.

[24] Costa G., Bagni N., Effects of polyamines on fruit-set of apple, Hortic. Sci. 18 (1991) 59-61.

[25] Rastegar S., Rahemi M., Zargari H., Changes in endogenous hormones in fruit during growth and development of date palm fruits, Am.-Eur. J. Agri. Environ. Sci. 11 (2011) 140-148.

[26] Messiaen J., Cambier P., Cutsem V.P., Polyamines and pectins, Plant Physiol. 113 (1997) 387-395.

[27] Martínez-Romero D., Valero D., Serrano M., Burló F., Carbonell A., Burgos L., Riquelme F., Exogenous polyamines and gibberellic acid effects on peach (Prunus persica L.) Storability improvement, J. Food Sci. 65 (2000) 288-294.

[28] Munteanu V., Gordeev V., Martea R., Duca M., Effect of gibberellin cross talk with other phytohormones on cellular growth and mitosis to endoreduplication transition, Int. J. Adv. Res. Biol. Sci. 1 (2014) 136-153.

[29] Carpita N.C., Gibeaut D.M., Structural models of primary cell walls in flowering plants: consistency of molecular structure with the physical properties of the walls during growth, Plant J. 3 (1993) 1-30.

[30] Lee E.J., Matsumura Y., Soga K., Hoson T., Koizumi N., Glycosyl hydrolases of cell wall are induced by sugar starvation in Arabidopsis, Plant Cell Physiol. 48 (2007) 405-413.

[31] Richard M., How to grow big peaches, Dep. Hort. Virginia Tech. Blacksburg, 2006.

[32] Kassem H.A., Al-Obeed R.S., Ahmed M.A., Omar A.K.H., Productivity, fruit quality and profitability of jujube trees improvement by preharvest application of agro-chemicals, Middle-East J. Sci. Res. 9 (2011) 628-637.

[33] Lang A., Turgor-related translocation, Plant Cell Environ. 6 (1983) 683-689.

[34] Remy E., Cabrito T.R., Baster P., Batista R.A., Teixeira M.C., Friml J., Sa-Correia I., Duque P., A major facilitator superfamily transporter plays a dual role in polar auxin transport and drought stress tolerance in Arabidopsis, Plant Cell 25 (2013) 901-926.

[35] Kermasha S., Barthakur N.N., Alli I., Changes in chemical composition of the Kew cultivar of pineapple fruit during development, J. Sci. Food Agri. 39 (1987) 317-324.

[36] Smirnoff N., The function and metabolism of ascorbic acid in plants, Ann. Bot. 78 (1996) 661-669.

[37] Davey M.W., Montagu M.V., Inze D., Sanmartin M., Kanellis A., Smirnoff N., Benzie I.J.J., Strain J.J., Favell D., Fletcher J., Plant L-ascorbic acid: chemistry, function, metabolism, bioavailability and effects of processing, J. Sci. Food Agri. 80 (2000) 825-860.

[38] Singleton V.L., Chemical and physical development of the pineapple fruit. I. Weight per fruitlet and other physical attributes, J. Food Sci. 30 (1965) 98-104.

[39] Bartholomew D.P., Paull R.E., Pineapple, in: Monselise P. (Eds). CRC Handbook of Fruit Set and Development. Boca Raton, Florida: CRC Press, 1986.

[40] Kermasha S., Barthakur N.N., Alli I., Changes in chemical composition of the Kew cultivar of pineapple fruit during development, J. Sci. Food Agri. 39 (1987) 317-324.

[41] Smith B.G., Harris P.J., Polysaccharide composition of unlignified cell walls of pineapple (Ananas comosus [L.] Merr.) fruit, Plant Physiol. 107 (1995) 1399-1409. 